https://doi.org/10.18485/iipe_euchanges.2021.ch10

\title{
IN SEARCH OF A EUROPEAN UNION GRAND STRATEGY IN THE INDO-PACIFIC
}

\author{
Iulia Monica OEHLER-ŞINCAI ${ }^{1}$
}

\begin{abstract}
The main aim of the paper is to summarize the arguments in favour of the EU entering the competition for more influence in the 'valuesdriven' Indo-Pacific. The paper will explore why key international actors support the designation 'Indo-Pacific' instead of 'Asia-Pacific', and why the European Union, an important investor, trader and donor, is motivated to define more clearly its priorities in this space, without excluding cooperation with China, which modelled the regional order the most in the last decade. The investigation will focus also on the synthetic interpretation of the EU's relations with significant strategic partners, including the ASEAN, China and India. At the same time, it will address the strategies related to the Indo-Pacific, already adopted by three EU countries, namely France, Germany and the Netherlands, providing a solid foundation for a common EU strategy in the rules-based Indo-Pacific. The common ground of these strategies is the complex objective of fair rules and norms and conflict avoidance, prerequisites of high-quality growth both regionally and globally. The EU is reconfirmed as a normative power, but also as an actor attempting 'to become a more equal partner to the United States'. The research question is related to the EU alternatives to exert its optimal influence in the Indo-Pacific. The theoretical framework has its roots in Alfred Mahan's sea power theory, Sir Halford Mackinder's heartland theory, and also Karl Haushofer's Indo-Pacific thalassocracy, concentrated in China's Belt and Road Initiative and reactions against this large-scale project. The alternative projects launched by Japan, India, the US, Australia and the EU since 2017, alone, in duo or trio formats, have not generated the expected results. In the meanwhile, China itself, under external pressure and alongside the gradual process of 'learning by doing' put more emphasis on quality infrastructure, sustainable development and
\end{abstract}

${ }^{1}$ Senior Researcher, Institute for World Economy of the Romanian Academy, Bucharest, Romania. E-mail: oehler.sincai@gmail.com 
sustainable debt. Therefore the author, having as support an extensive literature review and official documents, concludes that the Indo-Pacific is better off with the EU as a catalyst, especially as regards quality infrastructure and sustainable development. But to gain such as role, it needs a Grand Strategy supported by all its member states, which is not an easy task having in mind their various attitudes and positions towards key actors in the region, such as the US and China.

Keywords: The Indo-Pacific, the EU, strategy, security, values and norms, multilateralism, partnership, cooperation, connectivity, quality infrastructure, sustainable development

\section{INTRODUCTION}

The paper starts from the research question related to the best way for the EU to exert its influence in the Indo-Pacific, underlining that divide et impera strategies should be avoided. Stoking tensions between India and China, for instance, by using 'sticks' against China and 'carrots' for India would finally lead to threats for all partners. Instead, forging ties between China and India is a strong fundament for peace and stability.

Narratives denigrating another country do not bring prosperity. Instead, a conciliatory approach and more intense efforts to generate trust between partners are needed. The Covid-19 pandemic deepened the rifts between nations and underscored once again that chase after profit remains the supreme goal even when humanity is in danger. In this context, the EU should seek more influence in the region in order to bring more benefits to the world economy and humanity as a whole.

Following this rationale, the paper is structured in four main sections. The first one defines the Indo-Pacific and the motivations for this denomination instead of Asia-Pacific, as well as the key supporters of this transition from the continental geography (with China and Russia as core actors) to the maritime side perspective. The second section underlines that the European Union has an active presence in the Indo-Pacific. However, it is missing from the overwhelming majority of strategic documents and speeches of key leaders in the region. Consequently, the EU has to strengthen its networks in the region, with countries, country groups, institutions, by reiterating its sound principles and its support for development, without excluding any actor from its cooperation initiatives. The third section details the French, German and Dutch strategies of the Indo-Pacific, a solid base for a common EU strategy in the Indo-Pacific. The fourth section synthesizes potential objectives of the EU in this space, such 
as efforts to generate trust among partners (beyond sound principles, rules and norms), freer trade, economic development (starting from the 17 Sustainable Development Goals), and solutions 'to become a more equal partner to the United States'.

\section{DEFINITION OF THE INDO-PACIFIC AND THE EU PRESENCE IN THE REGION}

The Asia-Pacific is an axis mundi region, concentrating the overwhelming share of the world's population, gross world product, economic growth, international trade and investment flows, and China is the focal point of the economic transformations in the region. Nowadays, no entity can have the status of a genuine global player unless it has a strong presence in this space, not only economically, but also institutionally and politically. China drew more and more attention to its capabilities with the launch of the unmatched Belt and Road Initiative (BRI) in 2013, making the whole world understand that it does not intend to keep a low profile anymore, but instead it wants to take the place it deserves in the system of international relations.

Starting with 2011, a firm 'US pivot' to this region was evident. However, it was abruptly interrupted by President Donald Trump in 2017, through the withdrawal from a series of relevant international agreements and the support for a harmful deglobalization process, culminating with the USChina trade war and the intention of decoupling from China. Under President Joe Biden, the US' return to multilateralism is evident and the alliances in the region will be once again reshaped.

At present, the designation 'Indo-Pacific' is preferred to 'Asia-Pacific' by many key actors aiming to contain China and to a lesser extent Russia (already affected by the Western sanctions and the sharp decrease in oil prices). The 'Indo-Pacific' has an 'anti-Chinese connotation' (Camroux, 2020). It is a political term and is closely linked to various aspects of the American-Chinese rivalry (Heiduk\&Wacker, 2020). It has reappeared at a time when China increased its economic, political and military power at a level considered $a$ threat for the already established powers, after China's rise had been for decades one of the most important factors shaping the complex system of international relations.

In this section, we underscore why relevant countries support more and more this appellative and why it is high time for the European Union to define more clearly its priorities in this region without excluding cooperation with China. 


\section{A brief chronology of the official declarations in favour of the extended Indo-Pacific}

The term Indo-Pacific, coined in the 1920s by one of the 'fathers of geopolitics', Karl Haushofer, was consigned to oblivion until 2007. In 2007, the former Japanese Prime Minister Shinzo Abe mentioned the term 'confluence' of the two oceans, Indian and Pacific, in a speech at the Indian Parliament, paraphrasing the title of the book written in the $17^{\text {th }}$ century by the Mughal Prince Muhammad Dara Shikoh (Abe, 2007). In that speech, the goal of deepening cooperation with India was evident. Almost a decade later, at the Tokyo International Conference on Africa's Development in 2016, the same Prime Minister presented the Free and Open Indo-Pacific (FOIP) strategy (Abe, 2016), with the rationale to boost cooperation between Japan and African countries, in a time when China and India had the lead in cooperation with the African continent.

Japan was also the country that launched the Security Dialogue of the Four ('Quad' or G4) in 2007, together with the United States, India and Australia, as a reaction to China's economic and military rise. As of 2019, the promotion of a 'Free and Open Indo-Pacific' represented a priority area of Japan's foreign policy with the declared objective to develop this region as "international public goods" that bring stability and prosperity for any country' (Ministry of Foreign Affairs of Japan, 2019).

In turn, the Australian Government defined the new Indo-Pacific power relations in the 'White Papers on Defense' of 2013 and 2016 and the 'Foreign Policy White Paper' (Australian Government, 2013; 2016; 2017), focusing on the relations between the great powers, the US retaining 'its significant global lead in military and soft power' and China, 'the most important trading partner for most of the region's economies and a major investor', 'a large aid donor and lender to the region'.

Nevertheless, the concept of 'Indo-Pacific' accompanied by attributes such as free, open, inclusive, stable, secure and prosperous gained true international recognition and spread only after the adoption of the National Security Strategy by the US in December 2017 (The White House, 2017) and its reiteration by the US representatives at relevant international meetings. This space is defined as 'stretching from the west coast of India to the west coast of the United States, the most populated and dynamic part of the world'.

In his speech at the Shangri-La Dialogue (Singapore) of June 2018, the Indian Prime Minister Narendra Modi presented his own vision of the free, 
open, inclusive, stable, secure and prosperous region, from the western coast of North America to the eastern shores of Africa, further expanding the space defined in the National Security Strategy of the United States. Narendra Modi reiterated the Indian Government's vision in the IndoPacific, concentrated in one word, 'Sagar' (meaning ocean in Hindi): Security and Growth for All in the Region (Modi, 2018). Mukherjee (Mukherjee, 2019) synthesizes the essence of India's vision of the region in six elements: inclusivity, ASEAN's centrality, the rules-based order, equal access to the commons, trade liberalization and connectivity. On the one hand, India rejects the Chinese Belt and Road Initiative. On the other hand, it participates in the Asian Infrastructure Investment Bank with headquarters in Beijing. In the Sino-Indian strategic partnership, there are thorny issues (border disputes, Pakistan, rivalry), but also solid grounds for cooperation.

In June 2019, the Association of Southeast Asian Nations (ASEAN) ${ }^{2}$ published its own 'Outlook on the Indo-Pacific', focusing on partnerships in the framework of the East Asia Summit (EAS), ${ }^{3}$ for instance. The ASEAN combines cooperation with China with hedging against potential threats.

The European Parliament, in its documents, repeatedly stressed the importance of a European Indo-Pacific Strategy, in the context of elevating the EU's role as a global actor (European Parliament, 2020; 2021). The following are considered essential: the Asia-Europe Meeting (ASEM) ${ }^{4}$ and a global EU Connectivity Strategy 'as an extension of the current EU-Asia Connectivity Strategy in order to align our connectivity philosophy and connectivity policies with the goal of strengthening the EU's role as a true and indispensable geopolitical and geo-economic actor with a single narrative and as a cross-cultural enabler, and to strengthen partnerships with democracies around the world which share our fundamental values' (European Parliament, 2020).

From the three possible approaches to the Indo-Pacific (equidistance retaining the previous term Asia-Pacific and avoiding the use of IndoPacific; alignment to the majority of interpretations; autonomy - defining

2 Brunei Darussalam, Cambodia, Indonesia, Laos, Malaysia, Myanmar, Philippines, Singapore, Thailand and Vietnam.

${ }^{3}$ The EAS means the ASEAN plus 6 (Australia, China, India, Japan, New Zealand and South Korea) and the US and Russia since 2011.

${ }^{4}$ It comprises 53 partners: The European Union, the ASEAN Secretariat, 30 European and 21 Asian countries. 
an EU understanding of the Indo-Pacific, related to its particular economic, security and normative interests in the region) (Heiduk\&Wacker, 2020), the EU has already chosen its own way. The EU intends to become' a more equal partner to the United States' and 'to strengthen its role as a reliable partner worldwide, a preferred 'partner of choice' for third parties, a principled, but not dogmatic, honest broker, an actor of reference for conflict resolution and mediation, which promotes diplomacy and dialogue as the preferred way to play a constructive role in global conflicts, as a leading promoter of sustainable development and a major contributor to the multilateral framework, but also as a global actor that is ready to act autonomously and decisively when necessary to defend the EU's own values and interests, that takes responsibility by ensuring its own security and promoting international peace and stability, based on the principles and values of the UN Charter and as enshrined in international law, with respect for the international rules-based order' (European Parliament, 2021).

\section{Why the Indo-Pacific instead of the Asia-Pacific?}

The Economic and Social Commission for Asia and the Pacific (ESCAP) has at present 53 members and 9 associate members, including France, the Netherlands and the United Kingdom since 1947. These have a major influence in the region from a historical perspective through the British East India Company (1600-1857), the Dutch East India Company (1602-1799) and the French East India Company (1664-1769), but also by the multiple forms of manifestation of colonialism until 1942-1944. The three countries have reactivated their ambitions to become global powers again. The United Kingdom separated from the EU, with an ambitious vision of strong partnerships with Commonwealth ${ }^{5}$ countries (especially India) and France and the Netherlands, as member states of the EU under the vision of the EU Global Strategy of 2016 and more recently under the guidance of the Geopolitical Commission, relying also on international partnerships.

The Indo-Pacific is an extended, enlarged Asia-Pacific, having the Indian and Pacific Oceans at its core. The focus is moved from the continental side to the maritime one (especially from the perspective of maritime security).

\footnotetext{
${ }^{5}$ An intergovernmental organization consisting of 54 states (mostly former territories of the British Empire), among the member states being: Australia, New Zealand, Canada, India, Malaysia, Singapore, Bangladesh, Brunei, Pakistan and South Africa.
} 
The region also includes countries of the East coast of Africa. India becomes a key actor, wooed by opponents of China, not only from the perspective of containing the latter but also from that of doing business with India. And it offers India a preferential position, like compensation for its unfulfilled goal to join the Asia-Pacific Economic Cooperation Forum. It can be described as a strategy of using 'sticks' against China and 'carrots' for India, when tensions between the two neighbours are at a new climax for various reasons, including border disputes. In view of the already established powers, China has a too strong economic, political and military role (reflected by initiatives such as the Belt and Road) and, 'as a steadfast member of developing countries' promotes a new type of international relations, based on 'mutual respect, equality and mutual benefit' (Xi, 2021). By generalising the designation 'Indo-Pacific', the continental part of Asia (with China and Russia) is not anymore in the spotlight, but instead, the attention is focused on the maritime ways, with a whole set of issues, such as territorial disputes with China, maritime security, alternative trade routes (Grieger, 2016).

In this extended area not only the countries of Asia-Pacific but also the states of the American continent with access to the Pacific Ocean and the African countries bordering the Indian Ocean, compose a group of over 80 actors, out of which 25 are the most important (participants with overlapping memberships in the Asia-Pacific Cooperation Forum APEC, the Regional Comprehensive Economic Partnership RCEP - or ASEAN+6 - and the Comprehensive and Progressive Agreement for Trans-Pacific Partnership CPTPP).

\section{EU, MISSING FROM THE INDO-PACIFIC?}

The European Union has an active presence in the region but is missing from the overwhelming majority of strategic documents and speeches of key leaders in the region. The European Union's ties with this space are not reflected only via trade, investment, development assistance but also through its normative power (good governance, the rule of law, human rights), with intense relations with various partners. The EU's roles in the region are on multiple levels: economic, institutional and related to security. Ten strategic partners of the EU (all, with the exception of Brazil) are from the extended Indo-Pacific (China, India, Japan, Russia, South Korea, but also the US, Canada, Mexico, South Africa and the ASEAN). 
The EU-US partnership is 'the largest and most complex economic relationship in the world' (USTR, 2020). In terms of foreign direct investment (FDI), the United States represents the most important partner for the EU, as underscored by Chart 1. Around one-third of the EU and the US FDI flows are with each other.

CHART 1: EU INWARD AND OUTWARD FDI STOCKS IN RELATION WITH RELEVANT PARTNERS IN 2018 (EUR BILLION)

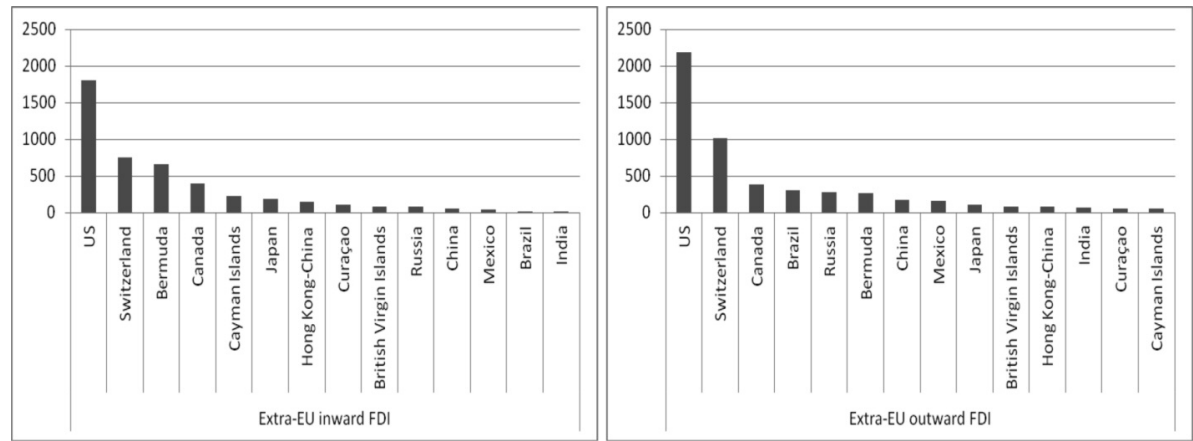

Source: Eurostat (2020a; 2020b)

As regards trade in goods, in general, the degree of dependency on countries of the Indo-Pacific on the EU internal market is much larger than vice-versa. Only the US has a larger share in the EU exports (18\%) than the EU in the US exports (16.2\%), and China a larger share in the EU imports $(18.7 \%)$ than the EU in China's imports $(12.3 \%)$. Chart 2 reflects the interdependencies between the EU27 and eight actors from the Asia-Pacific, namely: China, the ASEAN, South Korea, the Quad countries and New Zealand (denominated here as P8 for statistical reasons). 
CHART 2: THE DEGREE OF DEPENDENCY OF THE EU ON VARIOUS COUNTRIES OF THE INDO-PACIFIC AND VICE-VERSA, EXPORTS AND IMPORTS, 2019 (\%)
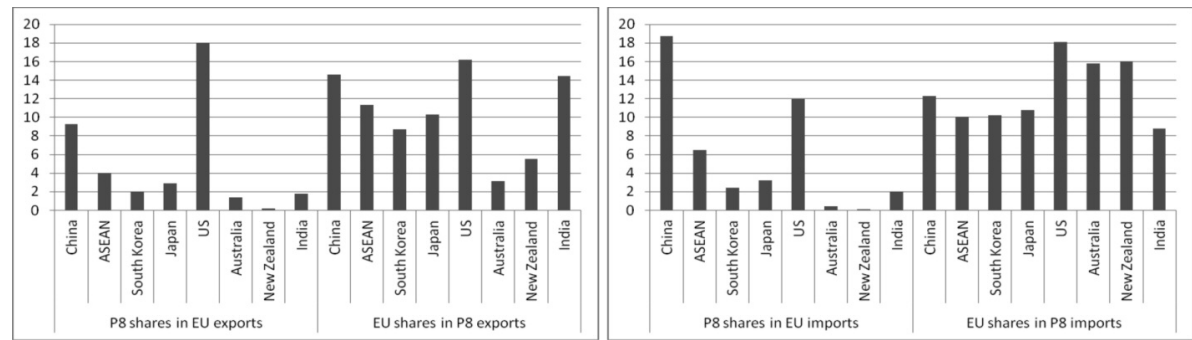

Source: DG Trade (2020).

Taking into account both flows (export plus import), the EU is the most important trade partner for the US, China and India and the third for the ASEAN (as a group), South Korea, Japan, Australia and New Zealand. But which is the first trade partner for the ASEAN, South Korea, Japan, Australia and New Zealand? It is China, with shares of 22.5\%, 23.3\%, 20.9\%, 32.5\% and $23.9 \%$, respectively. In recent years, China has been the fourth key partner for the US $(13.5 \%$ of the US trade flows, after the EU, Mexico and Canada), the second for the EU (13.8\%, after the US), and the third for India $(10.7 \%$, after the EU and the US). It explains why the first of the three principles proposed by the European Parliament as regards relations with China is (1) 'cooperate where possible', followed by: (2) 'compete where needed' and (3) 'confront where necessary' (European Parliament, 2021).

As compared with vocal countries in favour of a Free and Open IndoPacific (especially the Quad), the EU is a latecomer in defining its official position. In recent $\mathrm{EU}$ documents, the guiding principles of cooperation with the Indo-Pacific region ('openness, prosperity, inclusiveness, sustainability, transparency, reciprocity and viability') are underscored and also taken into account future military-to-military exchanges (European Parliament, 2020).

A more active presence in the Indo-Pacific is targeted not only by the documents of the EU institutions, but also by member states and groups of states. For instance, the Ministers of Foreign Affairs of France, Germany and Poland, meeting in Paris on 15 October 2020, in the Weimar Triangle format, underscored that 'the EU needs to adopt an ambitious agenda in the IndoPacific region to respond to the rise of unilateralism and regional instability. In this respect, France, Germany and Poland recall their commitment to the adoption of a specific European strategy for the Indo-Pacific, with the aim 
of promoting a common approach in this region, in cooperation with likeminded countries, including the transatlantic partners, and with a particular emphasis on the promotion of multilateralism openness, inclusiveness and cooperation, also with a view to reinforcing the EU's cohesion' (Ministère de l'Europe et des Affaires Étrangères, 2020).

France, Germany and the Netherlands adopted individual strategies related to this region, which will be analysed from a comparative perspective in the following section. France and the Netherlands have historical ties with countries in this space, and Germany appears for years as a strong supporter of more robust economic relations, as underscored for instance by the Nürnberg Declaration of March 2007 on the Enhanced Partnership with the ASEAN countries. Under the German Presidency of the EU Council in the first half of 2007, Germany sent a clear signal for cooperation with the ASEAN in multiple fields (political, security, economic, energy, climate change, development).

Nevertheless, the EU-ASEAN relations have not been as successful as expected, as underscored by at least three arguments: (1) negotiations for a free trade agreement (FTA) with a regional grouping of seven ASEAN member states started in July 2007, but were soon suspended, in December 2009; (2) trade and/or investment negotiations were started with seven ASEAN countries, but only two were concluded, with Singapore and Vietnam (the FTA with Singapore entered into force on 21 November 2019 and that with Vietnam on 1 August 2020); (3) the ASEAN had already entered into strategic partnerships with Australia, New Zealand, China, India, Japan, South Korea, and also the United States and Russia before it concluded a strategic partnership with the EU on 1 December 2020.

In this context, it must be also remembered that negotiations for the Bilateral trade and investment agreement with India (BTIA) were launched in June 2007 and interrupted in 2013 because of differences of opinion. However, starting from 2016, the bilateral partnership entered a new phase. First, at the 13th bilateral summit on 30 March 2016 in Brussels, the Action Agenda 2020 was adopted, with specific initiatives in areas such as politics, security, human rights and global challenges. Second, the EU and India announced in July 2017 a mechanism to facilitate EU investment in India. Third, at the 14th bilateral summit, held in New Delhi on 6 October 2017 (the year of 55 years of diplomatic relations), India and the EU expressed their commitment to strengthening the bilateral economic partnership and, at the same time, the intention to re-launch the negotiations for the broadbased and mutually beneficial BTIA, while announcing the launch of a 
platform for energy and climate change cooperation and a partnership for sustainable urbanization. Fourth, the 15th EU-India online summit on 15 July 2020, concluded with the adoption of the 'EU-India Strategic Partnership: A Roadmap for $2025^{\prime}$, underscores the political will to intensify bilateral cooperation (Oehler-Şincai, 2019).

All these are in strong contrast to the increasingly strained relations of the EU with China, after 2016. In that year, the European Commission and the High Representative of the Union for Foreign Affairs and Security Policy agreed on 'Elements for a new EU strategy on China': (1) 'reciprocity, a level playing field and fair competition across all areas of cooperation'; (2) 'respect for the rule of law and human rights'; (3) the intention to 'take full account of the EU's close relationships with the US and other partners' (EC-HR, 2016). The summits of 2016 and 2017 ended without a Joint Communiqué. In 2019, it was adopted the 'EU-China, A Strategic Outlook'. China was described as 'a systemic rival promoting alternative models of governance' and the EU proposed ten specific actions, including those related to the security of the 5G networks and security risks posed by foreign investment in critical assets, technologies and infrastructure (EC-HR, 2019).

It should be added that at the end of 2020, under the German Presidency of the European Council, the EU-China Comprehensive Agreement on Investment (CAI) was concluded 'in principle' after 35 rounds of negotiations over the course of more than seven years. In a context where cooperation with China is relevant from a European, as well as a multilateral perspective, the European Commission and Germany support CAI, the European Parliament is against it, while the conflicting interests of the EU member states still persist.

\section{FRENCH, GERMAN AND DUTCH STRATEGIES ON THE INDO-PACIFIC, IN A TIME WHEN COMPETITION FOR INFLUENCE IN THE REGION IS ON THE RISE}

France, with territories and military presence in the Indian and Pacific Oceans, started to define its strategy in the Indo-Pacific in 2018. Its contours were set out by President Emmanuel Macron firstly with the Indian Prime Minister Narendra Modi in March 2018, referring to their common vision in the Indian Ocean and secondly in the French President's speech at Garden Island, Sydney, on 2 May 2018. The synthetic document 'French Strategy in Asia-Oceania up to 2030' was presented in August 2018 (Ministère de l'Europe et des Affaires Étrangères, 2018). 
It followed the 'French Strategy in the Indo-Pacific - For an Inclusive Indo-Pacific' (Ministère de l'Europe et des Affaires Étrangères, 2019a) and the more elaborated document 'France's Defence Strategy in the IndoPacific' of 2019, where are underscored 'four strategic ambitions' of this 'sovereign nation of the Indo-Pacific': (1) defend and ensure the integrity of the French sovereignty, protection of French nationals, territories and Exclusive Economic Zones, taking into account that 1.6 million French citizens live in this space; (2) contribute to the security of regional environments through military and security cooperation; (3) 'maintain a free and open access to the commons, in cooperation with our partners, in a context of global strategic competition and challenging military environments' and (4) 'assist in maintaining strategic stability and balances through a comprehensive and multilateral action' (Ministère de l'Europe et des Affaires Étrangères, 2019b).

Among the strategic partnerships and dialogues are emphasized those with Australia, Canada (sectoral partnerships), China, India, Indonesia, Japan, Mexico, Singapore, South Africa, South Korea, the United Arab Emirates, the United States and Vietnam (Ministère de l'Europe et des Affaires Etrangères, 2019a).

France's principles are a rules-based multilateral order, rejection of unilateral ambitions and restrictions to freedom of navigation in the international air-sea commons, strategic balances against terrorism, the proliferation of weapons of mass destruction, and erosion of the legitimacy of democratic regimes.

In around 20 pages of the 'France's Defence Strategy in the Indo-Pacific', the word 'security' is used 97 times, 'military' 76 times, as compared to 'cooperation' 58 times, 'trade', 'climate' and 'aid' 3 times, 'energy' once and 'investment' not at all. India and the Indian Ocean are mentioned 41 times. China appears 32 times, Europe and the European Union around 30 times, the United States around ten times, similar to Japan, while the ASEAN only three times.

'In addition to the particularly strong defence relationship with the United States', France relies on cooperation with the other three Quad countries (Japan, Australia, India), based on the same values and concerns 'about emerging challenges'.

One can remark France's narrow focus on security issues, in contrast to Germany's broad perspective (Duchâtel\&Mohan, 2020). In around 70 pages, Germany's Policy Guidelines for the Indo-Pacific of September 2019 details its eight interests in the region: (1) peace and security; (2) diversifying and 
deepening relations; (3) rejection of unipolarity as well as bipolarity; (4) securing open shipping routes; (5) open markets and free trade; (6) digital transformation and connectivity; (7) protecting our planet and (8) countering disinformation in the region by increasing the availability of fact-based information.

The Federal Government is guided by seven principles: (1) European action, the German guidelines being considered as a contribution 'to the development of a European strategy for approaching the Indo-Pacific'; (2) multilateralism; (3) the rules-based order; (4) commitment to the 2030 Agenda and the Paris Climate Agreement; (5) human rights; (6) inclusivity (the third attribute of the Free, Open and Inclusive Indo-Pacific, underlined by India) and (7) a partnership among equals (strongly supported by China).

Germany pays special attention to the regional institutional framework, including the East Asia Summit (where the EU is searching for a more active role), the ASEAN Regional Forum (where the EU is a member), the two multilateral development banks, the Asian Development Bank (ADB) and the Asian Infrastructure Investment Bank (AIIB), the Pacific Islands Forum, the Mekong River Commission, the Asia-Europe Meeting (AEM), the Bay of Bengal Initiative for Multi-Sectoral Technical and Economic Cooperation (BIMSTEC), the South Asian Association for Regional Cooperation (SAARC), and the Indian Ocean Rim Association (IORA).

Beyond general objectives and goals, Germany puts emphasis on various cooperation fields with multiple partners, e.g., the digital transformation, sustainable infrastructure, climate change and environment protection, people-to-people exchanges via culture, education, science, the conclusion of EU free trade agreements with additional countries in the Indo-Pacific and with the ASEAN as a whole in the longer term, with the aim to avoid unilateral dependencies by diversifying partnerships. In this context, it is worth mentioning that 'free trade' is repeated 36 times. Germany refrains from criticizing its partners and has a balanced and nonbiased position.

The guidelines prepared by the Dutch government and published in November 2019 (ten pages) have a different perspective as compared to the French and German, as they put emphasis on the EU guidance and in most cases, the Netherlands and the EU are mentioned together. The 'EU' and 'Europe' appear in the text more than 100 times. The US is mentioned five times, Japan 15 times, the ASEAN 18 times, India 18 times, China and the South China Sea 26 times. The designation Indo-Pacific alternates with AsiaPacific, especially when statistics are presented (for the Netherlands, the 
Asia-Pacific region is the largest extra-EU export market, $11 \%$ of the Dutch exported goods goes to this region, while $22.5 \%$ of the Dutch imports comes from Asia). The region is understood through its core countries, namely the ASEAN, China, India, Japan, South Korea, Australia and New Zealand.

When enumerating the strategies already adopted by key actors in this space, after mentioning the US 'Free and Open Indo-Pacific', but also those of Australia, the ASEAN, India, Japan, South Korea, France and Germany, the document identifies the Belt and Road Initiative, through its Maritime Silk Road, as the 'China Indo-Pacific Strategy'. It is underscored that the EU does not yet have its own Indo-Pacific Strategy and the Netherlands believes that it is desirable for the EU to develop its own vision of the Indo-Pacific, focused on the EU cooperation with this region, according to its own agenda. It is revealed the importance of cooperation with 'like-minded democracies and open market economies'. The main goals are related to the rules-based order, democracy and human rights, sustainable trade, security and stability, maritime security, climate change, global health and poverty reduction. The countries in the Indo-Pacific are faced with two competing superpowers and are in search of economic and security anchors, in a period when the leeway for sovereign choices is becoming increasingly limited. The EU is one of the largest investors and donors in the region, with the Netherlands in the top 5. The Covid-19 crisis has accelerated ongoing geopolitical trends, pointing to the need for international cooperation to combat the virus and mitigate the negative economic consequences. 'Covid-19' is mentioned 9 times, while 'security' 31 times, 'cooperation' 42 times, 'trade' around 40 times, 'climate' 25 times, 'energy' 12 times, 'investment' 12 times, 'infrastructure' 6 times (including digital infrastructure). One of the major cooperation fields proposed by the Netherlands is digital cooperation, as part of the EU Connectivity Strategy, from cybersecurity and internet regulation to innovation, artificial intelligence, e-commerce, data transfer, privacy and digital sovereignty of countries (Rijksoverheid, 2020).

Elaborated during the presidency of Donald Trump, when the United States imposed a new vision of the world order, based on its own interests and objectives, nationalism, protectionism and unilateralism and when the EU-US relationship was often marked by tensioned moments, all the three strategies point to the importance of multilateralism. China also supports multilateralism and it is considered an important partner by the EU countries. However, these expect from China more results in the direction of sustainable development, elimination of existing market access 
asymmetries, the entire support for fair competition and democratic values and a peaceful settlement of disputes.

\section{EU IN THE INDO-PACIFIC: ANY GRAND STRATEGY IN SIGHT?}

The EU Global Strategy of 2016 (EEAS, 2016), defining strategic priorities such as 'a credible Union', 'a responsive Union' and 'a joined-up Union' was followed by a more active stance in the Indo-Pacific: the participation of the President of the European Council in the ASEAN summits starting with 2017, the completion of negotiations for the 'new generation' free trade agreements with Singapore, Vietnam and Japan and the adoption in September 2018 of a Strategy for connecting Europe and Asia. The EU negotiations for trade agreements with countries such as Indonesia, Australia and New Zealand are going on, and the resumption of negotiations with the whole group of ASEAN countries is not ruled out in the near future.

On 1 December 2020, the EU signed the long-awaited strategic partnership agreement with the ASEAN. On 2 December 2020, the European Commission and the High Representative for European Security and Foreign Affairs issued a Joint Communication to the European Council and the European Parliament proposing 'A New EU-US Agenda for Global Change', pointing to the goals of deepening cooperation 'with like-minded partners in the region' and working closely with the US 'to align our strategic objectives and support democratic progress' (EC-HR, 2020). The new Agenda reiterates China's role, as 'a negotiating partner for cooperation, an economic competitor, and a systemic rival', as stated in the Strategic Outlook of March 2019. It also reconfirms the EU's intention to coordinate its position with the US as much as possible: 'As open democratic societies and market economies, the EU and the US agree on the strategic challenge presented by China's growing international assertiveness, even if we do not always agree on the best way to address this. The new EU-US Dialogue on China will provide a key mechanism for advancing our interests and managing our differences'.

Although the EU-China Comprehensive Agreement on Investment (CAI) was concluded 'in principle' in December 2020, the EU will not give up its normative power, the EU FDI screening mechanism, or the 5G toolbox. It will continue to push China for better market access for the EU companies, a fairer investment environment (prohibition of forced 
technology transfers, new rules for the state-owned enterprises, transparency of subsidies) and sustainable development (e.g., including the protection of fundamental labour rights, commitments on the environment and climate) (European Commission, 2021; 2020a; 2020b; 2020c).

In the European Parliament resolution of 20 January 2021 on the implementation of the Common Foreign and Security Policy, there is synthesized one complex objective of the EU in the rules-based Indo-Pacific, namely safeguarding peace, stability and the freedom of navigation. In this regard, several directions of action are mentioned: (1) Tempering tensions in the region, by contributing to the dispute resolution and preventing unilateral actions, through constructive dialogue; (2) expanding cooperation with 'important like-minded partners in the Indo-Pacific region, such as Japan, India, South Korea, Australia and New Zealand'; 6 (3) positioning the EU 'as a partner of choice in a changing geopolitical order' for states and institutions alike, including the ASEAN and (4) 'developing a European Indo-Pacific strategy based on EU principles and values, which may include joint military exercises between Australia and NATO in the Pacific'.

The economic goal is mentioned only tangentially (in the context of 'China's assertive public diplomacy', which 'has made a number of countries co-dependent on its investment and loans') and indirectly (with no explicit reference to the region): 'The EU should actively increase its presence and visibility in partner states worldwide as a major investor and donor of development assistance'. It is evident that economic cooperation is a core component of the EU strategy towards the Indo-Pacific.

This demonstrates that the EU continues in order to be a regulatory power, supports cooperation and partnerships for development, and does not exclude cooperation with China. What China has not managed through the BRI, the EU might do together with China and other countries in the Indo-Pacific. China's powerful initiative is brilliant, but it needs support from the developed countries. In this way, China might lose the geopolitical advantages automatically accompanying the BRI, but will win in economic and credibility terms. The EU should become the pacifist factor in the region, offering credibility to cooperation among actors with various systems. It might become the catalyst

\footnotetext{
${ }^{6}$ This recalls the address by the vice-president of the European Commission, Josep Borrell, at the annual German Ambassadors' Conference in Berlin in May 2020: "We need a more robust strategy for China, which also requires better relations with the rest of democratic Asia. That's why we must invest more in working with India, Japan, South Korea et cetera".
} 
of 'stakeholder capitalism', in the sense given by Klaus Schwab, founder and executive chairman of the World Economic Forum (Schwab, 2019).?

Alfred Mahan's sea power theory, Sir Halford Mackinder's heartland theory and also Karl Haushofer's Indo-Pacific thalassocracy are verified in this context. China's Belt and Road Initiative, including both land and sea theories (the first reflected by the 'Belt', the second by the 'Road') would have had success if it had been proposed by a developed power or an alliance of developed countries. Aware of the development power of this initiative, useful not only for China but also for other developing countries, the developed world rejected this bold project having China's signature, labelling it as a 'debt trap'. Instead, alternatives were proposed, such as the Japanese-Indian Asia-Africa Growth Corridor (2017), the US Indo-Pacific Economic Vision (2018), the EU Strategy on Connecting Europe and Asia (2018) and the US-Australia-Japan Trilateral Partnership on Infrastructure Investment in the Indo-Pacific (2018) and the EU-Japan Partnership on Sustainable Connectivity and Quality Infrastructure (2019). Nevertheless, like-minded actors have not added real projects and funds to their proposed initiatives until now (Okano-Heijmans, 2019).

China started to redefine and rebrand the BRI, attaching particular importance to the sustainability of projects negotiated, agreed and implemented under the BRI, in accordance with the Green Investment Principles. This change is not only the result of external pressure (expressed through documents such as the 'EU-China - A Strategic Outlook', as well as concrete actions and alliances against China), but also the gradual process of 'learning by doing', emphasizing that 'sustainable development' and 'sustainable debt' are essential. These take into account the environmental, social and governance considerations (ESG) but also new technologies (the acronym ESTG), reflecting the gradual transition from 'value-driven' to 'values-driven' investment (Zaman\&Oehler-Şincai, 2020).

Infrastructure development has emerged as a source of geostrategic tensions, especially under the narrative (by developed countries but also

\footnotetext{
${ }^{7}$ He defines three types of capitalism: (1) "shareholder capitalism", praised by most Western companies, with the main objective to maximize profits; (2) "state capitalism", which entrusts the government with the task of establishing the direction of the national economy and which is present not only in China but in many other world economies; and (3) "stakeholder capitalism", taking into account the environmental, social and governance considerations (ESG), recommended by himself since 50 years ago.
} 
developing countries such as India) considering the ambitious Chinese BRI as a 'debt trap'. Nevertheless, cross-border infrastructure is considered the next frontier for the economic integration of the Indo-Pacific, a region characterized by significant infrastructure gaps. Infrastructure development is at the heart of national development strategies in most developing countries of the Indo-Pacific (Wilson, 2020). Table 1 exemplifies major infrastructure proposals and development banks that support infrastructure projects in the Indo-Pacific.

TABLE 1: EXEMPLIFICATION OF RELEVANT INDO-PACIFIC INFRASTRUCTURE INITIATIVES

\begin{tabular}{|l|l|l|l|}
\hline \multicolumn{1}{|c|}{ Initiatives } & Leader/members & Proposed budget & \multicolumn{1}{c|}{ Financing } \\
\hline $\begin{array}{l}\text { Belt and Road } \\
\text { Initiative (2013) }\end{array}$ & China & $\begin{array}{l}\text { Estimated USD } \\
1.000 \text { billion }\end{array}$ & $\begin{array}{l}\text { FDI, ODA, loans, } \\
\text { technical } \\
\text { assistance }\end{array}$ \\
\hline $\begin{array}{l}\text { Expanded } \\
\text { Partnership } \\
\text { for Quality } \\
\text { Infrastructure } \\
\text { (2016) }\end{array}$ & Japan & USD 200 billion & $\begin{array}{l}\text { FDI, ODA, loans, } \\
\text { technical } \\
\text { assistance }\end{array}$ \\
\hline & Asian \\
$\begin{array}{l}\text { Development } \\
\text { Bank }\end{array}$ & 68 members & $\begin{array}{l}\text { USD 147 billion } \\
\text { subscribed capital } \\
\text { Developing Asia } \\
\text { needs to invest } \\
\text { \$1.7 trillion per } \\
\text { year in } \\
\text { infrastructure, } \\
\text { taking into } \\
\text { account the efforts } \\
\text { to tackle climate } \\
\text { change (mitigation } \\
\text { and adaptation) }\end{array}$ & $\begin{array}{l}\text { Loans, grants, } \\
\text { technical } \\
\text { assistance }\end{array}$ \\
\hline $\begin{array}{l}\text { Asian } \\
\text { Infrastructure } \\
\text { Investment Bank }\end{array}$ & $\begin{array}{l}103 \text { approved } \\
\text { members by the } \\
\text { end of 2020 }\end{array}$ & $\begin{array}{l}\text { USD 100 billion } \\
\text { subscribed capital }\end{array}$ & Commercial loans \\
\hline $\begin{array}{l}\text { Master Plan on } \\
\text { ASEAN } \\
\text { Connectivity }\end{array}$ & $\begin{array}{l}10 \text { ASEAN } \\
\text { members }\end{array}$ & $\begin{array}{l}\text { Regulatory } \\
\text { dialogue, policy } \\
\text { harmonisation and } \\
\text { capacity building }\end{array}$ \\
\hline
\end{tabular}




\begin{tabular}{|c|c|c|c|}
\hline Initiatives & Leader/members & Proposed budget & Financing \\
\hline $\begin{array}{l}\text { Greater Mekong } \\
\text { Subregion }\end{array}$ & $\begin{array}{l}\text { Cambodia, China, } \\
\text { Laos, Myanmar, } \\
\text { Thailand, Vietnam }\end{array}$ & - & $\begin{array}{l}\text { Regulatory } \\
\text { dialogue, policy } \\
\text { harmonisation and } \\
\text { capacity building }\end{array}$ \\
\hline $\begin{array}{l}\text { APEC Framework } \\
\text { on Connectivity }\end{array}$ & 21 APEC members & - & $\begin{array}{l}\text { Regulatory } \\
\text { dialogue, policy } \\
\text { harmonisation and } \\
\text { capacity building }\end{array}$ \\
\hline $\begin{array}{l}\text { Japanese-Indian } \\
\text { Asia-Africa } \\
\text { Growth Corridor } \\
\text { (AAGC) (2017) }\end{array}$ & Japan and India & $\begin{array}{l}\text { Potential sources: } \\
\text { ADB }\end{array}$ & $\begin{array}{l}\text { Proposal is } \\
\text { considered "too } \\
\text { broad and vague" }\end{array}$ \\
\hline $\begin{array}{l}\text { US-Australia- } \\
\text { Japan Trilateral } \\
\text { Partnership on } \\
\text { Infrastructure } \\
\text { Investment in the } \\
\text { Indo-Pacific } \\
(2018)\end{array}$ & $\begin{array}{l}\text { US-Australia- } \\
\text { Japan }\end{array}$ & $\begin{array}{l}\text { US International } \\
\text { Development } \\
\text { Finance } \\
\text { Corporation, the } \\
\text { Japan Bank for } \\
\text { International } \\
\text { Cooperation } \\
\text { (JBIC), Australian } \\
\text { Infrastructure } \\
\text { Financing Facility } \\
\text { for the Pacific } \\
\text { (AIFFP), national } \\
\text { sources (e.g. for } \\
\text { the project in } \\
\text { Palau) }\end{array}$ & $\begin{array}{l}\text { FDI, ODA, loans, } \\
\text { technical } \\
\text { assistance }\end{array}$ \\
\hline $\begin{array}{l}\text { US Indo-Pacific } \\
\text { Economic Vision } \\
(2018) \\
\text { International } \\
\text { Development } \\
\text { Finance } \\
\text { Corporation } \\
\text { (2019) }\end{array}$ & United States & USD 60 billion & $\begin{array}{l}\text { FDI, ODA, } \\
\text { loans, technical } \\
\text { assistance }\end{array}$ \\
\hline
\end{tabular}




\begin{tabular}{|c|c|c|c|}
\hline Initiatives & Leader/members & Proposed budget & Financing \\
\hline $\begin{array}{l}\text { EU Strategy on } \\
\text { Connecting } \\
\text { Europe and Asia } \\
\text { (2018) }\end{array}$ & EU & $\begin{array}{l}\text { Multiple pillars: } \\
\text { geographical, } \\
\text { thematic, rapid } \\
\text { response }\end{array}$ & $\begin{array}{l}\text { Neighbourhood, } \\
\text { Development and } \\
\text { International } \\
\text { Cooperation } \\
\text { Instrument (NDIC } \\
\text { I), part of the 2021- } \\
2027 \text { multiannual } \\
\text { financial } \\
\text { framework (MFF) }\end{array}$ \\
\hline $\begin{array}{l}\text { EU-Japan } \\
\text { Partnership } \\
\text { on Sustainable } \\
\text { Connectivity } \\
\text { and Quality } \\
\text { Infrastructure } \\
\text { (2019) }\end{array}$ & EU and Japan & $\begin{array}{l}\text { EUR } 60 \text { billion, } \\
\text { used by the EU to } \\
\text { attract further } \\
\text { investment from } \\
\text { development } \\
\text { banks and private } \\
\text { investors. }\end{array}$ & $\begin{array}{l}\text { FDI, ODA, } \\
\text { loans, technical } \\
\text { assistance }\end{array}$ \\
\hline
\end{tabular}

Source: Authors own representation based on Wilson (2020), Taniguchi (2020), ADB Institute (2018), https:/ / www.adb.org/about/members, https://www.aiib.org/en/about-aiib/index.html.

It is worth noting that these initiatives do not explicitly exclude cooperation with China on infrastructure development, and the international and regional context (dominated by low-interest rates, and concerns about weak economic growth or recessions) stimulates such projects (Rajah, 2020; Berkofsky, 2019). However, most of the initiatives launched as a response to the BRI have not generated a critical mass of expected results, as exemplified by the Japanese-Indian joint initiative. The Asia-Africa Growth Corridor (AAGC) just added to the list of initiatives considered as alternatives to the BRI. On 23 May 2017, shortly after the first Belt and Road Forum in China, the Indian Prime Minister Narendra Modi announced the AAGC initiative, led by India and Japan to support Africa's development. The AAGC, an alternative to the BRI, a way to bring in consonance India's 'Act East' and Japan's 'Expanded Partnership for Quality Infrastructure' policies, and also to emphasize the solid foundations of their bilateral partnership (political liberalism, the market economy, the rule of law and democracy), has not generated the expected achievements (Taniguchi, 2020). 
It is also interesting to point to the increase of various actors' presence in the Indo-Pacific, amid the Covid-19 pandemic. For example, the 'Europe Team' has mobilized over EUR 800 million to fight the pandemic in the ASEAN countries. The virtual meeting of EU and ASEAN foreign ministers on 20 March 2020 and the stated objectives are pieces of evidence in this regard.

Beyond initiatives launched by the EU (as a whole) and individual countries' strategies on the Indo-Pacific, one can remark also the political will for intensification of bilateral relations. The India-Italy Joint Statement and Plan of Action 2020-2024, presented at the virtual summit between the two countries on 6 November 2020, suggested 'the importance of the IndoPacific region as a fundamental area for connecting Asia and Europe and stated their Countries' willingness to support all connectivity initiatives based on internationally recognised norms and standards, good governance, the rule of law, inclusiveness, transparency and level-playing field'. It was proposed also the establishment of Indo-Italian networks of Excellence in selected areas of mutual strength (cultural heritage preservation; renewable energy; life and environmental sciences; geo-hazards).' Spain has a strategic vision in Asia for 2018-2022. Portugal, with historical ties with India, intends to revive this partnership. The EU countries (including the Scandinavian ones) ${ }^{8}$ are also courting Indonesia. Austria supports the EU Connectivity Strategy as well as the Asia-Europe Meeting.

Such examples underscore the multitude of cooperation areas and the complex network of bilateral, trilateral and multilateral agreements led by the EU and its member states in the Indo-Pacific.

\section{CONCLUSIONS}

The presence and influence in the Indo-Pacific represent an undeniable barometer in terms of the strength of a country or a group of states. Since 2016 (when the EU Global Strategy was adopted), and culminating with the announcement by the European Parliament in January 2021 to support an EU Strategy in the region, one can remark the sustained efforts of the European Union towards acquiring a more relevant role in this space.

${ }^{8}$ Please consult, for exemplification, the Ministry of Foreign Affairs of the Republic of Indonesia (2020). 
The European Union, as a strong supporter of multilateralism and a relevant normative power, as a powerful economic actor and a tough advocate of sustainable development, can play a larger role in the IndoPacific in the future. The conciliatory approach and enhanced efforts to generate trust among partners, freer trade, economic development (especially via the much-needed infrastructure development) and solutions 'to become a more equal partner to the United States' are high on the agenda.

Recently, the EU intensified its initiatives in the Indo-Pacific. On 1 December 2020, the EU signed the long-awaited strategic partnership agreement with the ASEAN. On 2 December 2020, the European Commission and the High Representative for European Security and Foreign Affairs issued a Joint Communication to the European Council and the European Parliament proposing 'A New EU-US Agenda for Global Change'. Even the EU-China Comprehensive Agreement on Investment was concluded 'in principle' on 30 December 2020. The EU continues to be a regulatory power, supports cooperation and partnerships for development and does not exclude cooperation with China.

Among possible scenarios of the EU exerting its influence in the IndoPacific, the best one is that in which the EU, the US and China would cooperate. The Belt and Road Initiative and the Europe-Asia Connectivity project should be regarded as complementary and not antagonistic, and both may support good quality growth if environmental, social and corporate governance factors are taken into account.

The European Union has an active presence in the region, even if it is missing from the overwhelming majority of strategic documents and speeches of key leaders in the region. The European Union's ties with this space are not reflected only via trade, investment, development assistance but also through its normative power (good governance, the rule of law, human rights), with intense relations with various partners. The EU's role is at multiple levels: economic, institutional and related to security. Ten strategic partners of the EU are from the extended Indo-Pacific (China, India, Japan, Russia, South Korea, but also the US, Canada, Mexico, South Africa and the ASEAN). In recent EU documents, the guiding principles of cooperation with the Indo-Pacific region ('openness, prosperity, inclusiveness, sustainability, transparency, reciprocity and viability') are underscored and also taken into account future military-to-military exchanges.

France has had an Indo-Pacific strategy since 2019, detailed in two documents, where it describes itself as a 'nation of the Indo-Pacific'. Its declared goals in the region are related to settling crises and conflicts, 
strengthening partnerships, offering more support for multilateralism and promoting common goods. In turn, Germany adopted its strategy for the region in September 2020, aiming at diversifying its economic relations, but also securing open shipping routes, open markets and free trade, protecting the planet, giving an impetus to the digital transformation and connectivity and countering disinformation. It refrains from criticizing its partners and has a balanced and non-biased position. The Netherlands proposed a more succinct strategy in November 2020, based on values and norms, and chose a concrete field of regional cooperation, namely digital connectivity, as part of the EU Connectivity Strategy. All three EU member states are in favour of a future EU strategy in the Indo-Pacific. Besides, others, with various economic ties with this space (Italy, Spain, Portugal, Austria, Nordic Countries and Poland, for instance) are likely to express more interest in the Indo-Pacific in the near future.

The key to the future role of the EU in the Indo-Pacific remains a common position inside the EU regarding the Indo-Pacific, China, the US, priorities and cooperation in the region, which is difficult to achieve.

\section{REFERENCES}

Abe, S. (2016). Address by Prime Minister Abe Shinzo at the Opening Session of the Sixth Tokyo International Conference on African Development (TICAD VI), August 27, Kenyatta International Convention Centre (KICC), Nairobi, Kenya.

Abe, S. (2007). Speech by H.E. Mr. Abe Shinzo, Prime Minister of Japan, at the Parliament of the Republic of India 'Confluence of the Two Seas'.

ADB Institute (2018). Financing Infrastructure in Asia and the Pacific Capturing Impacts and New Sources, Tokyo, Japan.

ASEAN (2019). ASEAN Outlook on the Indo-Pacific, June, retrieved from https://asean.org/asean-outlook-indo-pacific/. Accessed 4 December 2020.

Australian Government (2013). Defence White Paper, Department of Defence, retrieved from https://www.defence.gov.au/whitepaper/ 2013/. Accessed 18 December 2020.

Australian Government (2016). 'Defence White Paper', Department of Defence, retrieved from https://www.defence.gov.au/WhitePaper/ Docs/2016-Defence-White-Paper.pdf. Accessed 4 December 2020. 
Australian Government (2017). 'Foreign Policy White Paper', Department of Foreign Affairs and Trade, November, retrieved from https://www.dfat.gov.au/publications/minisite/2017-foreign-policywhite-paper/fpwhitepaper/pdf/2017-foreign-policy-white-paper.pdf. Accessed 4 December 2020.

Berkofsky, A. (2019). Moving Beyond Rhetoric? The EU-Japan Strategic Partnership Agreement (SPA), Institute for Security and Development Policy, Issue Brief, April 9.

Borrell, J. (2020). Opening remarks to the annual German Ambassadors' Conference, Berlin, May 25, retrieved from https://eeas.europa.eu/ delegations/lao-pdr/79817/opening-remarks-annual-germanambassadors\%E2\%80\%99-conference_en. Accessed 20 November 2020.

Die Bundesregierung (2020). Leitlinien zum Indo-Pazifik, DeutschlandEuropa-Asien - Das 21. Jahrhundert Gemeinsam Gestalten [Guidelines for Indo-Pacific, Germany-Europe-Asia, Shaping the $21^{\text {st }}$ century together], retrieved from https://www.auswaertiges-amt.de/blob/ 2380500/33f978a9d4f511942c241eb4602086c1/200901-indo-pazifikleitlinien - 1-data.pdf . Accessed 25 January 2021.

Camroux, D. (2020). Europe rediscovers the Indo-Pacific, East Asia Forum.

DG Trade (2020). Trade statistics, retrieved from https://ec.europa.eu/ trade/policy/countries-and-regions/statistics/. Accessed 18 December 2020.

Duchâtel, M.\&Mohan, G. (2020). Franco-German Divergences in the IndoPacific: The Risk of Strategic Dilution, Institut Montaigne.

European Commission (2021). EU-China Comprehensive Agreement on Investment: Milestones and documents, retrieved from https:// trade.ec.europa.eu/doclib/press/index.cfm?id=2115, Accessed 25 January 2021.

European Commission (2020a). Key elements of the EU-China Comprehensive Agreement on Investment, Press release, December 30, Brussels, retrieved from https:/ / ec.europa.eu/commission/ presscorner /detail/en/ip_20_2542. Accessed 5 January 2021.

European Commission (2020b). O\&A: EU-China Comprehensive Agreement on Investment (CAI), December 30, Brussels, retrieved from https://ec.europa.eu/commission/presscorner/detail/en/QANDA_2 0_2543. Accessed 5 January 2021.

European Commission (2020c). EU-China Comprehensive Agreement on Investment - The Agreement in Principle, December 30, Brussels, 
retrieved from https://trade.ec.europa.eu/doclib/press/index.cfm?id= 2237. Accessed 5 January 2021.

European Commission and the High Representative of the European Union for Foreign Affairs and Security Policy (EC-HR) (2020). A new EU-US agenda for global change, Joint Communication to the European Parliament, the European Council and the Council, Brussels, retrieved from https://ec.europa.eu/info/sites/info/files/joint-communicationeu-us-agenda_en.pdf. Accessed 26 January 2021.

European Commission and the High Representative of the European Union for Foreign Affairs and Security Policy (EC-HR) (2019). EU-China, A Strategic Outlook, Brussels, retrieved from https:/ /ec.europa.eu/info/ sites/info/files/communication-eu-china-a-strategic-outlook.pdf. Accessed 29 January 2021.

European Commission and the High Representative of the European Union for Foreign Affairs and Security Policy (EC-HR) (2016). Elements for a new EU strategy on China, Joint Communication to the European Parliament and the Council, Brussels, retrieved from https://eeas. europa.eu/archives/docs/china/docs/joint_communication_to_the_eu ropean_parliament_and_the_council_-_elements_for_a_new_eu_ strategy_on_china.pdf. Accessed 15 January 2021.

European External Action Service (EEAS) (2016). Shared Vision, Common Action: A Stronger Europe - A Global Strategy for the European Union's Foreign and Security Policy, June, retrieved from https:/ / eeas.europa. eu/archives/docs/top_stories/pdf/eugs_review_web.pdf. Accessed 12 February 2021.

European Parliament (2021). European Parliament resolution of 20 January 2021 on the implementation of the Common Foreign and Security Policy - annual report 2020 (2020/2206(INI)), P9_TA-PROV(2021)0012, retrieved from https://www.europarl.europa.eu/doceo/document/ TA-9-2021-0012_EN.html. Accessed 22 January 2021.

European Parliament (2020). Report on connectivity and EU-Asia relations, 2020/2115(INI), December 17, retrieved from https:/ / www.europarl. europa.eu/doceo/document/A-9-2020-0269_EN.html. Accessed 19 January 2021.

Eurostat (2020a). Balance of payments statistics, retrieved from: https://ec.europa.eu/eurostat/web/balance-of-payments/data/ database, Accessed 27 January 2021. 
Eurostat (2020b). Trade and investment flows, DS-018995 and bop_its6_det, bop_fdi6_pos, retrieved from https://ec.europa.eu/eurostat/data/ database, Accessed 18 December 2021.

Grieger, G. (2016). China and the South China Sea issue, European Parliamentary Research Service, September, retrieved from https:// www.europarl.europa.eu/RegData/etudes/BRIE/2016/58667 1/EPRS_BRI(2016)586671_EN.pdf. Accessed 22 January 2021.

Haushofer, K. (1924). Geopolitik des Pazifischen Ozeans, Vowinckel, Berlin.

Heiduk, F. \& Wacker, G. (2020). From Asia-Pacific to Indo-Pacific, Significance, Implementation and Challenges, SWP Research Paper No. 9, German Institute for International and Security Affairs.

Lillehaugen, M. (2018). The 'Free and Open' Indo-Pacific: A Call for European Partnership, Asia Dialogue, Carnegie Endowment for International Peace, retrieved from https://carnegieendowment.org/ 2018/06/22/free-and-open-indo-pacific-call-for-european-partnershippub-76673. Accessed 15 October 2020.

Ministère de l'Europe et des Affaires Étrangères (2020). Joint statement by the Ministers for Foreign Affairs of the Weimar Triangle (France, Germany and Poland) - Jean-Yves Le Drian, Heiko Maas and Zbigniew Rau, retrieved from https://www.diplomatie.gouv.fr/en/countryfiles/germany/the-weimar-triangle/article/joint-statement-by-theministers-for-foreign-affairs-of-the-weimar-triangle. Accessed 15 October 2020.

Ministère de l'Europe et des Affaires Étrangères (2019a). French Strategy in the Indo-Pacific - For an Inclusive Indo-Pacific, retrieved from https:/ / www.diplomatie.gouv.fr/en/country-files/asia-and-oceania/the-indopacific-region-a-priority-for-france/. Accessed 22 January 2021.

Ministère de l'Europe et des Affaires Étrangères (2019b). French Strategy in the Indo-Pacific - For an Inclusive Indo-Pacific, retrieved from https:// www.diplomatie.gouv.fr/en/country-files/asia-andoceania/the-indo-pacific-region-a-priority-for-france/. Accessed 22 January 2021.

Ministère de l'Europe et des Affaires Étrangères (2018). Stratégie française en Asie-Océanie à l'horizon 2030 Vers un Espace Asiatique Indopacifique Inclusif [French strategy in Asia-Ocenania by 2030 towards an Inclusive Info-Pacific Asean Space], retrieved from https://www.diplomatie.gouv.fr/IMG/pdf/livre_blanc-com-_freng_cle876fb2-1.pdf. Accessed 22 January 2021. 
Ministry of Foreign Affairs of the Republic of Indonesia (2020). Indonesian Way - Minister of Foreign Affairs Retno Marsudi Encourages Green Economy Cooperation with Sweden, retrieved from https:// kemlu.go. $\mathrm{id} /$ portal/en/read/1911/berita/minister-of-foreign-affairs-retnomarsudi-encourages-green-economy-cooperation-with-sweden. Accessed 24 November 2020.

Ministry of Foreign Affairs of Japan (2019). Diplomatic Bluebook 2019, retrieved from https://www.mofa.go.jp/policy/other/bluebook/ 2019/html/chapter1/c0102.html\#sf01. Accessed 08 January 2021.

Modi, N. (2018). Prime Minister's Keynote Address at Shangri La Dialogue, Ministry of External Affairs, Government of India, retrieved from https:// www.mea.gov.in/Speeches-Statements.htm?dtl/29943/ Prime+Ministers+Keynote+Address + at + Shangri+La+Dialogue+June +0 1+2018. Accessed 27 November 2020.

Mukherjee, R. (2019). Looking West, Acting East: India's Indo-Pacific Strategy. Southeast Asian Affairs, 43-52. doi:10.2307/26939685

Oehler-Şincai, I.M. (2020). Confluences and divergences of some major actors' interests in the Indo-Pacific, Geostrategic Pulse, No. 281, pp. 10-18.

Oehler-Şincai, I.M. (2019). Economic Relations of the Great Powers in the Indo-Pacific in the Current Geopolitical Context, Institute for World Economy, Romanian Academy, 211 pages.

Office of the United States Trade Representative (USTR) (2020). 2020 Trade Policy Agenda and 2019 Annual Report of the President of the United States on the Trade Agreements Program, retrieved from https://ustr.gov/sites/default/files/2020_Trade_Policy_Agenda_and_ 2019_Annual_Report.pdf. Accessed 08 January 2021.

Okano-Heijmans, M. (2019). Empowering the EU-Japan Connectivity Partnership, Clingendael Magazine, November 4, retrieved from https://www.clingendael.org/publication/empowering-eu-japanconnectivity-partnership. Accessed 2 October 2020.

Rajah, R. (2020). Mobilizing the Indo-Pacific infrastructure response to China's Belt and Road Initiative in Southeast Asia, retrieved from https://www.brookings.edu/research/mobilizing-the-indo-pacificinfrastructure-response-to-chinas-belt-and-road-initiative-in-southeastasia/.

Rijksoverheid (2020). Indo-Pacific: een leidraad voor versterking van de Nederlandse en EUsamenwerking met partners in Azië [Indo-Pacific: guidelines for strengthening Dutch and EU cooperation with partners 
in Asia], retrieved from https://www.rijksoverheid.nl/documenten/ kamerstukken/2020/11/13/kamerbrief-inzake-beleidsnotitie-indopacific-een-leidraad-voor-versterking-van-de-nederlandse-en-eusamenwerking-met-partners-in-azie. Accessed 04 February 2021.

Schwab, K. (2019). Why we need the 'Davos Manifesto' for a better kind of capitalism, retrieved from https://www.weforum.org/agenda/2019/ 12/why-we-need-the-davos-manifesto-for-better-kind-of-capitalism/. Accessed 2 October 2020.

Taniguchi, T. (2020). Should We Forget about the Asia-Africa Growth Corridor?, Lettre du Centre Asie, retrieved from https:// www.ifri.org/ sites/default/files/atoms/files/taniguchi_asia_africa_growth_corridor 2020.pdf. Accessed 23 October 2020.

The White House (2017). National Security Strategy of the United States of America, retrieved from https://trumpwhitehouse.archives.gov/wpcontent/uploads/2017/12/NSS-Final-12-18-2017-0905.pdf. Accessed 18 December 2020.

Wilson, J. (2020). Infrastructure Choices and the Future of the IndoPacific. Security Challenges, vol. 16, no. 3, 2020, pp. 64-68, retrieved from www.jstor.org/stable/26924342. Accessed 04 February 2021.

Xi, J. (2021). Special Address by Chinese President Xi Jinping at the World Economic Forum Virtual Event of the Davos Agenda, January 25, retrieved from http://www.xinhuanet.com/english/2021-01/25/c_ 139696610.htm. Accessed 25 January 2021.

Zaman, G.\&Oehler-Sincai, I.M. (2020). ESTG BRI: Principles for a Sustainable Belt and Road Initiative, China-CEE Institute, retrieved from https:// china-cee.eu/working_papers/estg-bri-principles-for-asustainable-belt-and-road-initiative/. Accessed 05 February 2021. 